 \\ SEPA ENVIRONMENTAL
RESEARCH BRIEF
}

\section{Pollution Prevention Assessment for a Manufacturer of Folding Paperboard Cartons}

\author{
Harry W. Edwards', Michael F. Kostrzewa*, Michelle May*, \\ and Gwen P. Looby"
}

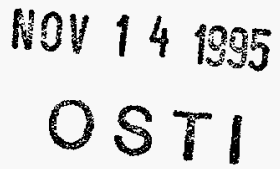

\begin{abstract}
The U.S. Environmental Protection Agency (EPA) has funded a pilot project to assist small and medium-size manufacturers who want to minimize their generation of waste but who lack the expertise to do so. In an effort to assist these manufacturers Waste Minimization Assessment Centers (WMACs) were established at selected universities and procedures were adapted from the EPA Waste Minimization Opportunity Assessment Manual (EPA/625/7-88/003, July 1988). That document has been superseded by the Facility Pollution Prevention Guide (EPA600/R-92/088, May 1992). The WMAC team at Colorado State University performed an assessment at a plant that manufactures folding paperboard cartons. Paperboard stock is cut to specific sheet sizes, printed using a six-color press, cut into carton patterns, folded, and glued. The assessment team's report detailing findings and recommendations, indicated that waste paperboard is generated in large quantities, and that the most significant cost savings can be achieved through collection and reuse of "step 1" solvent used in the printing system.
\end{abstract}

This Research Brief was developed by the principal investigators and EPA's National Risk Management Research Laboratory, Cincinnati, $\mathrm{OH}$, to announce key findings of an ongoing research project that is fully documented in a separate report of the same title available from University City Science Center.

\section{Introduction}

The amount of waste generated by industrial plants has become an increasingly costly problem for manufacturers and an additional stress on the environment. One solution to the

- Colorado State University, Department of Mechanical Engineering

* University City Science Center, Philadelphia, PA problem of waste generation is to reduce or eliminate the waste at its source.

University City Science Center (Philadelphia, PA) has begun a pilot project to assist small and medium-size manufacturers who want to minimize their generation of waste but who lack the in-house expertise to do so. Under agreement with EPA's National Risk Management Research Laboratory, the Science Center has established three WMACs. This assessment was done by engineering faculty and students at Colorado State University's (Fort Collins) WMAC. The assessment teams have considerable direct experience with process operations in manufacturing plants and also have the knowledge and skills needed to minimize waste generation.

The pollution prevention opportunity assessments are done for small and medium-size manufacturers at no out-of-pocket cost to the client. To qualify for the assessment, each client must fall within Standard Industrial Classification Code 20-39, have gross annual sales not exceeding $\$ 75$ million, employ no more than 500 persons, and lack in-house expertise in pollution prevention.

The potential benefits of the pilot project include minimization of the amount of waste generated by manufacturers, and reduction of waste treatment and disposal costs for participating plants. In addition, the project provides valuable experience for graduate and undergraduate students who participate in the program, and a cleaner environment without more regulations and higher costs for manufacturers.

\section{Methodology of Assessments}

The pollution prevention opportunity assessments require several site visits to each client served. In general, the WMACs follow the procedures outlined in the EPA Waste Minimization Pryted on Recycled Paper

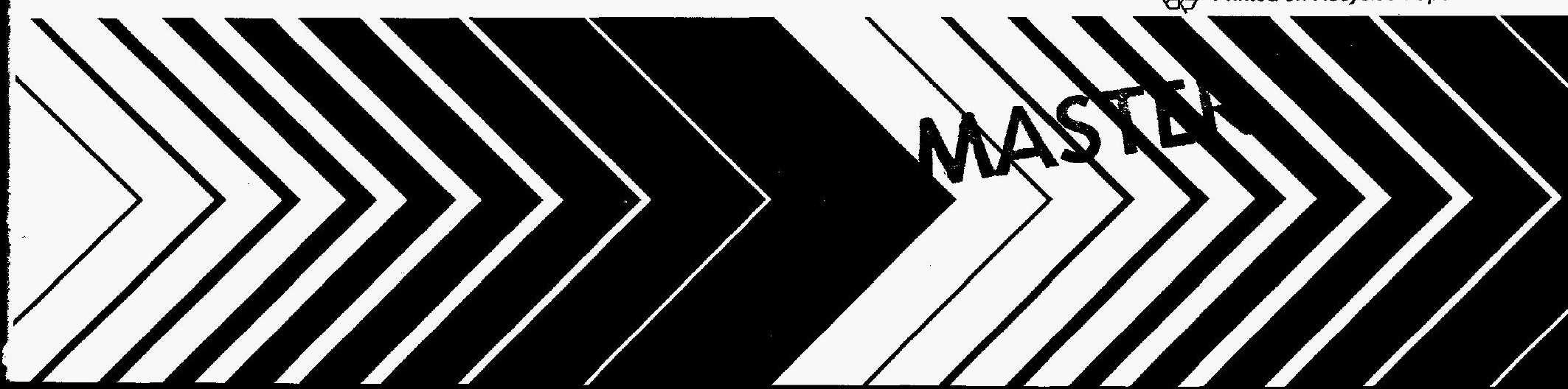


Opportunity Assessment Manual (EPA/625/7-88/003, July 1988). The WMAC staff locate the sources of waste in the plant and identify the current disposal or treatment methods and their associated costs. They then identify and analyze a variety of ways to reduce or eliminate the waste. Specific measures to achieve that goal are recommended and the essential supporting technological and economic information is developed. $\mathrm{Fi}$ nally, a confidential report that details the WMAC's findings and recommendations (including cost savings, implementation costs, and payback times) is prepared for each client.

\section{Plant Background}

This plant manufactures folding paperboard cartons. It operates approximately $2,200 \mathrm{hr} / \mathrm{yr}$ to produce about 1,200 tons of cartons annually.

\section{Manufacturing Process}

Paperboard rolls of various gauges are cut to specific sheet sizes in the sheeter machine. If required, the paper sheets are sent to the hydraulic cutter for trimming to smaller sheet sizes. The sheets are stacked on pallets and assigned a labeling code in preparation for printing.

For the past several years, the plant has used its six-color printing press exclusively. Two other presses-a two-color and a three-color-are also available. Printing plates are developed onsite using a recently installed photolithographic process. Printing plates are attached to five of the six press cylinders. Each cylinder transfers a different color to each sheet as it passes through the press. The sixth and final cylinder is used exclusively to apply a clear aqueous coating to the sheet, which gives the printed sheet a glossy appearance. Printed sheets are stacked at the end of the press to await die cutting.

The printed sheets are cut into carton sheets by one of four die cutters. The die cutter feeds the sheet through, cuts the desired carton pattern, and applies the fold impression. Die patterns used by the die cutters are produced onsite from metal strips and wood arranged on plywood slabs. Excess strips of paper are removed from cartons manually after die cutting in the stripping area. The stripped sheets are stacked on pallets and sent to either windowing or folding and gluing.

The large and small windower machines are used to apply a clear plastic film to cover carton openings. A glue wheel is used to apply a glue pattern on the carton to affix the film. Cartons are sent to one of three folding and gluing machines in which the carton sides are glued together. Glue is applied using a glue pot and glue pads in two of the machines and automatically in the third machine. Completed cartons are boxed and stored to await shipping.

An abbreviated process flow diagram for folding paperboard box manufacture is shown in Figure 1.

\section{Existing Waste Management Practices}

This plant already has implemented the following techniques to manage and minimize its wastes.

- Ink is collected from the color presses at the end of the day, returned to its proper container, and stored for reuse.

- Waste film from the photolithographic process is collected and shipped offsite for recycling.

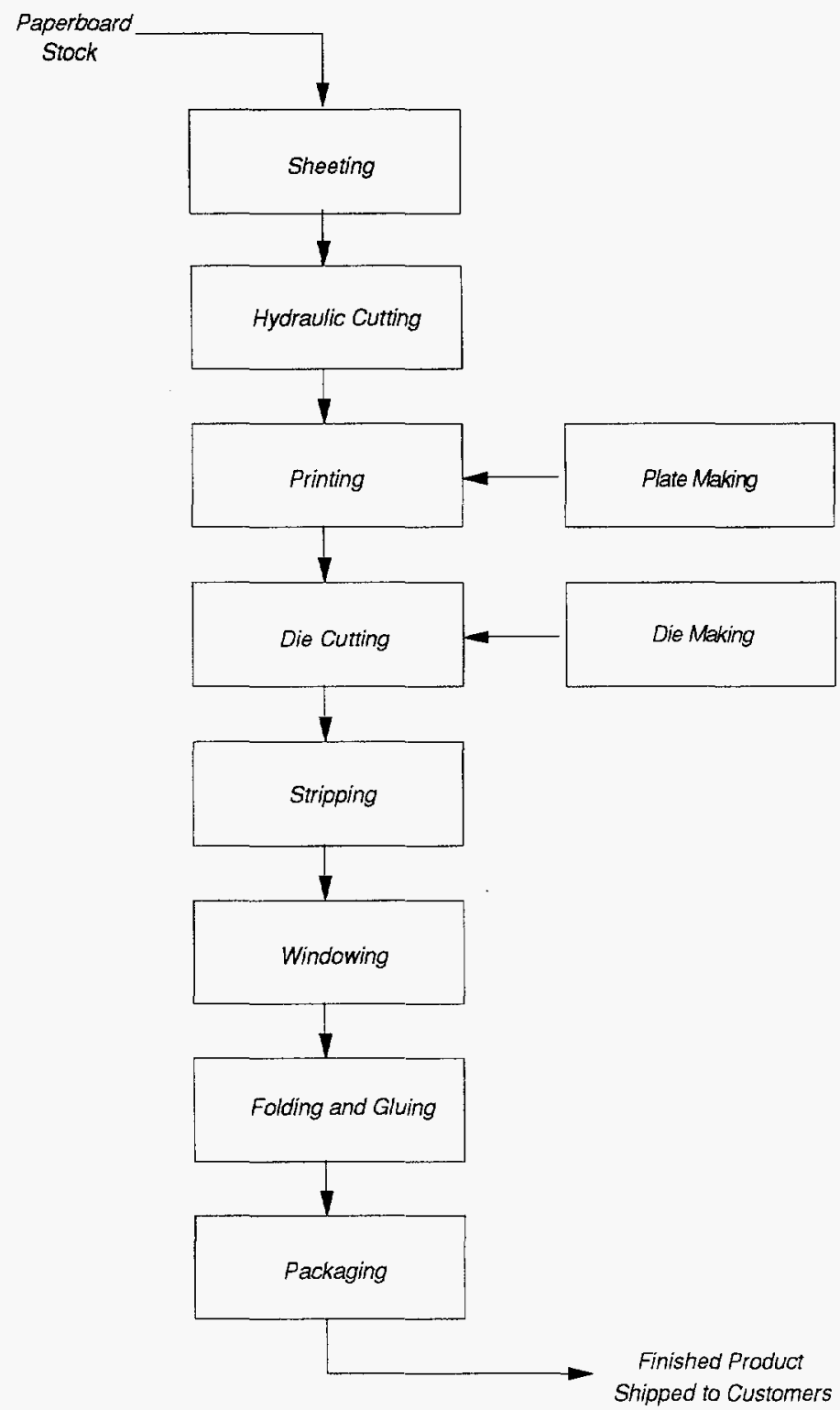

Figure 1. Abbreviated process flow diagram for folding paperboard carton manufacture.

- Waste paperboard instead of new paperboard is fed through the printing press at start-up until the printing quality meets specifications to avoid the generation of additional waste paperboard.

- Printed and non-printed waste paperboard is baled and shipped offsite for recycling.

\section{Pollution Prevention Opportunities}

The type of waste currently generated by the plant, the source of the waste, the waste management method, the quantity of the waste, and the annual waste management cost for each waste stream identified are given in Table 1.

Table 2 shows the opportunities for pollution prevention that the WMAC team recommended for the plant. The opportunity, the type of waste, the possible waste reduction and associated 


\section{DISCLAIMER}

This report was prepared as an account of work sponsored by an agency of the United States Government. Neither the United States Government nor any agency thereof, nor any of their employees, make any warranty, express or implied, or assumes any legal liability or responsibility for the accuracy, completeness, or usefulness of any information, apparatus, product, or process disclosed, or represents that its use would not infringe privately owned rights. Reference herein to any specific commercial product, process, or service by trade name, trademark, manufacturer, or otherwise does not necessarily constitute or imply its endorsement, recommendation, or favoring by the United States Government or any agency thereof. The views and opinions of authors expressed herein do not necessarily state or reflect those of the United States Government or any agency thereof. 


\section{DISCLAIMER}

Portions of this document may be illegible electronic image products. Images are produced from the best available original document. 
savings, and the implementation cost along with the simple payback time are given in the table. The quantities of waste currently generated by the plant and possible waste reduction depend on the production level of the plant. All values should be considered in that context.

It should be noted that, in most cases, the economic savings of the opportunities result from the need for less raw material and from reduced present and future costs associated with hazardous waste treatment and disposal. Other savings not quantifiable by this study include a wide variety of possible future costs related to changing emissions standards, liability, and employee health. It also should be noted that the savings given for each opportunity reflect the savings achievable when implementing each pollution prevention opportunity independently and do not reflect duplication of savings that would result when the opportunities are implemented in a package.

\section{Additional Recommendations}

In addition to the opportunities recommended and analyzed by the WMAC team, two other measures were considered. These measures were not analyzed completely because of insufficient data, implementation difficulty, or a projected lengthy payback. Since one or more of these approaches to pollution prevention may, however, increase in attractiveness with changing conditions in the plant, they were brought to the plant's attention for future consideration.

- Install a silver recovery unit onsite to recover dissolved silver from spent photographic fixer and wash water.

- Improve the existing paperboard recycling program. Suggested improvements include standardizing the type of board manufactured; improving the sorting of various types of waste board; automating the collection and baling operations; reducing the size of waste bales; and moving the waste board storage and baling unit outdoors.

This research brief summarizes a part of the work done under Cooperative Agreement No. CR -814903 by the University City Science Center under the sponsorship of the U.S. Environmental Protection Agency. The EPA Project Officer was Emma Lou George.

Table 1. Summary of Current Waste Generation

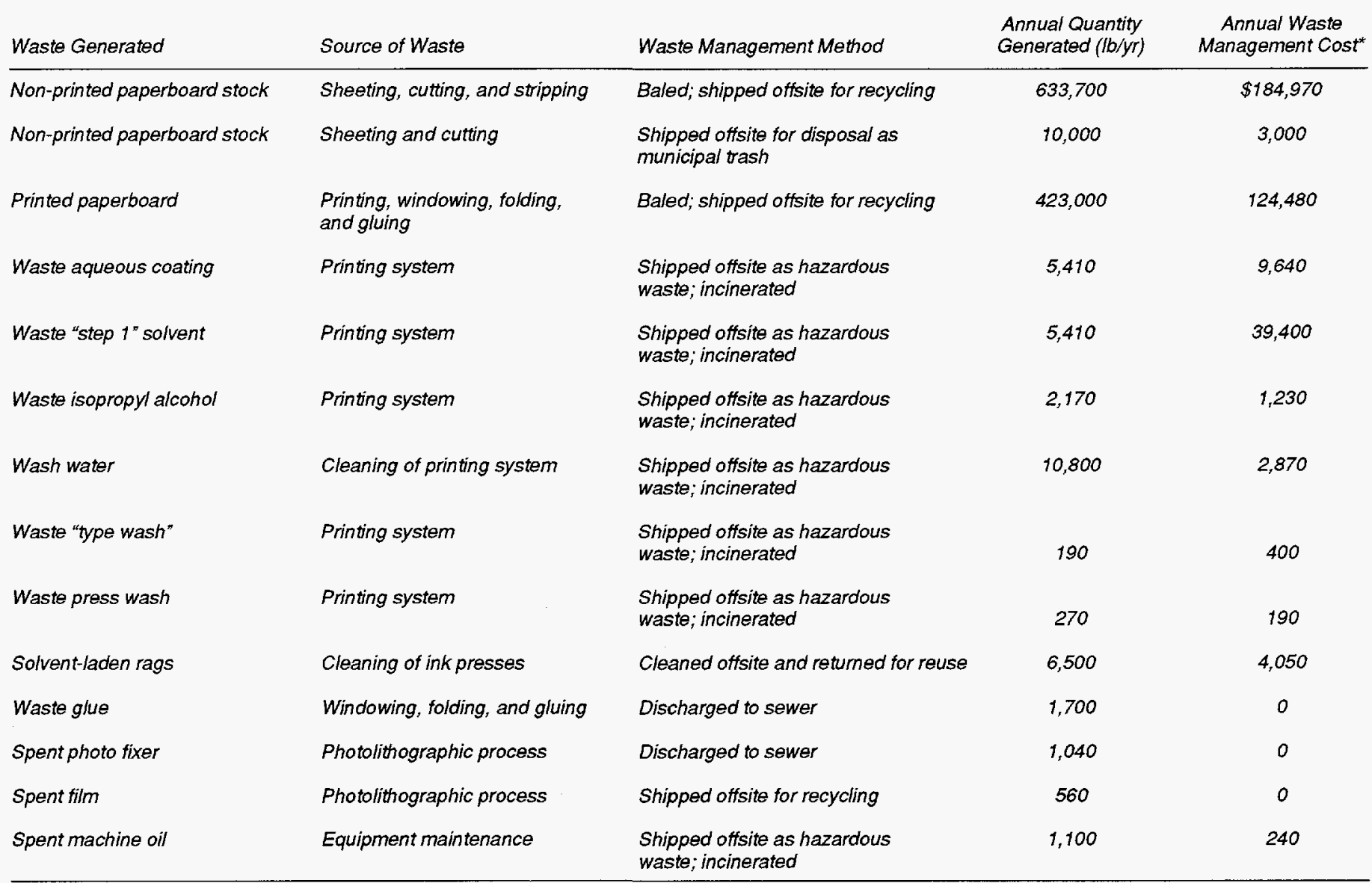

*Includes waste treatment, disposal, and handing costs and applicable raw material costs. 
Table 2. Summary of Recommended Pollution Prevention Opportunities

\begin{tabular}{|c|c|c|c|c|c|c|}
\hline \multirow[b]{2}{*}{ Pollution Prevention Opportunity } & \multirow[b]{2}{*}{ Waste Reduced } & \multicolumn{2}{|c|}{ Annual Waste Reduction } & \multirow{2}{*}{$\begin{array}{l}\text { Net Annual } \\
\text { Savings }\end{array}$} & \multirow{2}{*}{$\begin{array}{l}\text { Implementation } \\
\text { Cost }\end{array}$} & \multirow{2}{*}{$\begin{array}{c}\text { Simple } \\
\text { Payback (yr) }\end{array}$} \\
\hline & & Quantity (lb/yr) & Per Cent & & & \\
\hline $\begin{array}{l}\text { Collect and reuse part of the waste } \\
\text { "step 1" that does not mix with resid- } \\
\text { ual aqueous coating and water in the } \\
\text { printing system supply lines. }\end{array}$ & Waste "step 1 " solvent & 2,750 & 50 & $\$ 20,000$ & $\$ 0$ & 0 \\
\hline $\begin{array}{l}\text { Modity the aqueous coating cylinder } \\
\text { cleaning procedure to reduce waste } \\
\text { generation. A squeegee and rags } \\
\text { can be used to mechanically clean } \\
\text { the rubber pads and storage tray of } \\
\text { the printing system instead of using } \\
\text { water to flush out and clean the } \\
\text { entire system. The small quantity of } \\
\text { spent cleaning rags generated can be } \\
\text { shipped offsite for cleaning, returned, } \\
\text { and reused. }\end{array}$ & Wash water & 10,800 & 100 & 2,710 & 0 & 0 \\
\hline $\begin{array}{l}\text { Ship the waste lubricating oil offsite to } \\
\text { an oil recycler instead of shipping it to } \\
\text { a hazardous waste treatment, storage, } \\
\text { and disposal facility for incineration. } \\
\text { No waste reduction will result at the } \\
\text { plant site, but the plant can achieve } \\
\text { cost savings through implementing } \\
\text { this measure. }\end{array}$ & Spent machine oil & 0 & - & 210 & 500 & 2.4 \\
\hline
\end{tabular}

United States

Environmental Protection Agency

National Risk Management Research Laboratory (G-72)

Cincinnati, $\mathrm{OH} 45268$

Official Business

Penalty for Private Use

$\$ 300$

EPA/600/S-95/021
BULK RATE

POSTAGE \& FEES PAID

EPA

PERMIT No. G-35 